\title{
Hubungan prestasi belajar siswa kelas khusus olahraga dengan kecerdasan emosional
}

\author{
Andy Ardian ${ }^{1} *$, Sugeng Purwanto ${ }^{1}$, Deden Saepul Alfarisi ${ }^{2}$ \\ ${ }^{1}$ Program Studi Ilmu Keolahragaan, Program Pascasarjana, Universitas Negeri Yogyakarta. \\ Jalan Colombo No. 1, Karangmalang, Yogyakarta 55281, Indonesia. \\ ${ }^{2}$ Infrastucture University Kuala Lumpur. Jalan Ikram-Uniten, 43000 Kajang, Selangor, Malaysia \\ * Corresponding Author. Email: andyardian96@gmail.com
}

Received: 10 November 2019; Revised: 9 December 2019; Accepted: 12 December 2019

\begin{abstract}
Abstrak
Kelas khusus olahraga adalah kelas yang dikhususkan untuk mengembangkan prestasi olahraga tanpa mengesampingkan prestasi belajar. Prestasi belajar merupakan pencapaian hasil dari pembelajaran yang telah dilalui. Namun sampai saat ini belum adanya hasil penelitian yang mengungkapkan mengenai faktor yang mendorong prestasi belajar siswa khususnya kelas olahraga. Tujuan penelitian ini adalah untuk mengetahui apakah ada hubungan antara kecerdasan emosional terhadap prestasi belajar siswa kelas khusus olahraga. Penelitian ini merupakan penelitian kuantitatif dengan pendekatan deskriptif korelasi. Sampel pada penelitian ini adalah 40 siswa kelas khusus olahraga di SMAN 1 Ciparay. Instrument yang digunakan dalam penelitian ini adalah angket serta dokumentasi. Analisis data pada penelitian ini dihitung dengan bantuan microsoft excel 2007. Hasil penelitian mengungkapkan bahwa thitung dengan $\mathrm{t}_{\text {tabel }}(\mathrm{t}(2,042) \leq \mathrm{t}(0.369) \leq \mathrm{t}(2,042))$ berdasakan hasi tersebut menunjukan bahwa adanya pengaruh dan hubungan positif yang signifikan antara kecerdasan emosional terhadap hasil belajar siswa kelas khusus olahraga.
\end{abstract}

Kata Kunci: kecerdasan emosional, kelas khusus olahraga, prestasi belajar

\section{The relationship of learning achievement special students with emotional intelligence}

\begin{abstract}
Special sports classes are classes that are devoted to developing sports achievements without compromising learning achievement. Learning achievement is the achievement of the results of learning that has been passed. But until now there has been no research results that reveal the factors that encourage student learning achievement, especially sports classes. The purpose of this study was to determine whether there is a relationship between emotional intelligence on student achievement in special sports classes. This research is a quantitative study with a descriptive correlation approach. The sample in this study was 40 students of special sports class at SMAN 1 Ciparay. The instrument used in this study was a questionnaire and documentation. Analysis of the data in this study was calculated with the help of Microsoft Excel 2007. The results revealed that tcount with ttable $(t(2,042) \leq t(0.369) \leq t(2,042)$ based on the results showed that there was a significant positive influence and relationship between emotional intelligence on the learning outcomes of special sports class students.
\end{abstract}

Keywords: emotional intelligence, special class sports, learning achievement

How to Cite: Ardian, A., Purwanto, S., \& Alfarisi, D. (2019). Hubungan prestasi belajar siswa kelas khusus olahraga dengan kecerdasan emosional. Jurnal Keolahragaan, $7(2), \quad$ 126-134. doi:https://doi.org/10.21831/jk.v7i2.28103

doi https://doi.org/10.21831/jk.v7i2.28103

\section{PENDAHULUAN}

Kelas khusus olahraga memiliki tujuan yaitu mendidik, memfasilitasi, dan mengasah bakat siswa dalam bidang olahraga. Menurut (Mahendra, 2010) kelas olahraga adalah sebuah model pembinaan yang dilaksanakan di sekolah target yang melibatkan sekelompok siswa yang teridentifikasi "berbakat" olahraga (memiliki keunggulan olahraga) dalam lingkup sekolah. Kelas khusus dapat diartikan dimana beberapa peserta didik dikelompokkan berada dalam satu kelas khusus pada sekolah regular namun memperoleh 
Jurnal Keolahragaan 7 (2), 2019 - 127

Andy Ardian, Sugeng Purwanto, Deden Saepul Alfarisi

perlakuan akselerasi sehingga dapat menyelesaikan pendidikan di sekolah itu lebih awal dibanding kelas regular (Fitriyah, 2011; Pujiatmojo, 2012). Selain berprestasi dalam bidang olahraga siswa yang masuk dalam kelas ini diharuskan memiliki prestasi belajar yang baik dalam nilai akademik. Prestasi belajar ditandai dengan mendapatkan nilai baik dalam suatu materi pembelajaran. Sejalan dengan pernyataan tersebut (Retnowati et al., 2016) prestasi belajar adalah hasil yang diperoleh dari aktivitas belajar yang dilakukan pada bidang akademik yang ditunjukkan dengan perolehan nilai yang dituliskan di dalam rapor. Prestasi belajar juga dipengaruhi beberapa faktor seperti yang dikatakan (Narwoto \& Soeharto, 2013), faktor-faktor yang diduga mempunyai pengaruh kuat terhadap prestasi belajar antara lain faktor internal dan eksternal, lebih lanjut faktor internal yang dimaksudkan adalah kecerdsan intelektual (IQ) dan kecerdasan emosional (EQ). Dari beberapa faktor tersebut terdapat dua faktor yang sangat memberikan pengaruh besar yaitu kecerdasan intelektual (IQ) dan kecerdasan emosional (EQ) yang dimiliki masingmasing individu.

Kecerdasan emosional (EQ) sendiri memiliki pengertian yaitu kemampuan merasakan, memahami, dan secara selektif menerapkan daya dan kepekaan emosi sebagai sumber energi dan pengaruh yang manusiawi. Kecerdasan emosional (EQ) merupakan salah satu jenis kecerdasan yang dimiliki oleh manusia (Tridhonanto, 2010). Purnamasari et al. (2013) mengatakan kecerdasan emosional (EQ) adalah kemampuan mengenali, memahami perasaan diri dan orang lain (empati). Kemampuan memotivasi diri. Kemampuan mengelola emosi baik diri sendiri maupun hubungan dengan orang lain dan kemampuan berinteraksi dengan orang lain (social skill) yang sangat dibutuhkan setiap individu untuk meraih kesuksesan. Dari beberapa pengertian tersebut dapat disimpulkan bahwa kecerdasan emosional (EQ) adalah suatu kemampuan yang dimiliki oleh seseorang dalam mengenali, mengelola, dan mengekspresikan emosi yang dimiliki serta mampu membina hubungan dengan orang lain. Kecerdasan emosional juga merupakan gabungan dari semua kemampuan emosional untuk menghadapi seluruh aspek kehidupan.

Kecerdasan emosional (EQ) dapat dipengaruhi dan diberikan rangsangan dari luar untuk mengembangkanya. Dalam proses pembelajaran kecerdasan emosional (EQ) merupakan salah satu faktor penting dalam penentu keberhasilan siswa. Sejalan dengan pendapat tersebut,
(Rohmah, 2018) menyatakan bahwa kecerdasan intelektual (IQ) hanya menyumbang $20 \%$ bagi kesuksesan, sedangkan $80 \%$ adalah sumbangan faktor kekuatan-kekuatan lain, diantaranya adalah kecerdasan emosional atau Emotional Quotient (EQ) yakni kemampuan memotivasi diri sendiri, mengatasi frustasi, mengontrol desakan hati, mengatur suasana hati (mood), berempati serta kemampuan bekerja sama. (Chubba, 2007) bahwa IQ hanya berperan $20 \%$ dalam kesuksesan hidup seseorang, sedangkan selebihnya yang $80 \%$ adalah kecerdasan emosi, sosial, dan spiritualnya. (Goffreda et al., 2009) menjelaskan bahwa kecerdasan emosional (EQ) memiliki pengaruh yang baik terhadap keberhasilan dalam menyelesaikan study Kecerdasan emosional juga memberikan pengaruh baik dalam kerja lapangan mahasiwa, semakin besar kecerdasan emosional yang dimiliki oleh seseorang maka akan lebih baik saat bekerja dilapangan dan lebih cepat dalam menyelesaikan masa study. Dartija (2014) mengungkapkan bahwa adanya hubungan yang positif antara kecerdasan emosiaonal terhadap prestasi belajar siswa SMP Negeri 1 Sawang pada mata pelajaran olahraga. Lebih lanjut, Dartija (2014) menjelaskan bahwa kecerdasan emosianal dalam pembelajaran olahraga menjadi salah satu hal penting untuk menunjukan keberhasilan peserta didik dalam menerima dan menerapkan pembelajaran olahraga dengan baik. Hadiwijaya (2017) menyebutkan bahwa keberhasilan belajar siswa dipengaruhi oleh kecerdasan emosional yang dimilikinya. Lebih lanjut, dijelaskan bahwa dalam penelitian ini kecerdasan emosional yang mempengaruhi keberhasilan belajar siswa meliputi, pengendalian diri, pengendalian manajemen waktu, motivasi, hubungan dengan lingkungan sekitar.

Luan and Blegur (2018) menjelaskan bahwa mahasiswa yang memiliki kecerdasan emosional (EQ) yang baik akan mampu mendapatkan prestasi yang lebih baik dibandingkan dengan mahasiswa yang memiliki kecerdasan emosional (EQ) kurang baik. Andiri et al. (2017) mengatakan bahwa korelasi kecerdasan emosional dan prestasi hanya $0,5 \%$ data kecerdasan emosional memberikan pengaruh langsung terhadap prestasi akademik sisanya sebesar $99,5 \%$ atau $(100 \%$ $0,5=99,5 \%$ ) disebabkan oleh faktor-faktor teknis dan non teknis lainnya.

Berdasarkan kajian literatur penelitian yang telah disebutkan, peneliti mencermati bahwa sudah banyak hasil penelitian yang mengungkapkan bahwa prestasi belajar yang didapatkan siswa dipengaruhi dan dihubungkan dengan 
Jurnal Keolahragaan 7 (2), 2019 - 128

Andy Ardian, Sugeng Purwanto, Deden Saepul Alfarisi

kecerdasan emosional (EQ) yang dimiliki siswa. Namun, peneliti mencermati mengenai masih kurangnya penelitian yang membahas mengenai hubungan antara kecerdasan emosional (EQ) terhadap prestasi belajar khususnya pada kelas khusus olahraga yang didalamnya mengharuskan siswa berprestasi di bidang olahraga dan bidang prestasi akademis. Oleh karena itu penulis menilai perlunya pembaharuan hasil penelitian mengenai hubungan antara kecerdasan emosional (EQ) dengan hasil belajar pada siswa dikelas khusus olahraga. Diharapkan hasil penelitian ini mampu menjadikan rujukan untuk melandasi peningkatan prestasi belajar siswa di kelas khusus olahraga pada pengembangan di bidang kecerdasan emosional (EQ) yang dimiliki masingmasing individu.

\section{METODE}

Penelitian ini menggunakan metode penelitian deskriptif korelasi. Populasinya yaitu kelas XI IPS yang berjumlah 105 orang siswa, pada penelitian ini mengambil satu kelas dari kelas khusus olahraga yaitu kelas XI-11 IPS di SMA Negeri 1 Ciparay. Subjek dalam penelitian ini adalah siswa kelas khusus olahraga di SMA Negeri 1 Ciparay yaitu satu kelas dari seluruh kelas khusus olahraga yang jumlahnya 40 siswa. Variabel dalam penelitian ini yang menjadi variabel bebas yaitu kecerdasan emosional sebagai variabel (X) sedangkan yang menjadi variabel terikatnya yaitu prestasi belajar siswa sebagai variabel (Y). Instrumen pada penelitian ini berupa Angket dan Dokumentasi. Data yang didapatkan dihitung menggunakan uji kesamaan dua rata-rata untuk mengetahui ada atau tidaknya pengaruh antara kecerdasan emosional dengan prestasi belajar. Kemudian untuk mengetahui hubungan antara kedua variable tersebut dilakukan uji kebermaknaan koefisien korelasi. Perhitungan hasil penelitian menggunakan bantuan Microsoft Excel 2007.

\section{HASIL DAN PEMBAHASAN}

\section{Hasil}

Penelitian yang dilakukan dihitung menggunakan uji kesamaan dua rata-rata terlebih dahulu untuk mengetahui pengaruh antara variabel (X) terhadap variabel (Y). Kemudian akan dilakukan uji kebermaknaan koefisien kolerasi untuk mengetahui adakah hubungan antara kedua variabel tersebut. Sebelum melakukan perhitungan, diperlukanya melakukan uji prasyarat analisis terlebih dahulu, uji prasyarat analisis yang dimaksudkan dalam penelitian ini adalah uji normalitas dan uji homogenitas. Hasil dari uji normalitas dan homogenitas dapat dilihat pada tabel dibawah ini:

\section{Hasil Uji Normalitas Menggunakan Microsoft} Excel 2007

Perhitungan data untuk pengujian normalitas dilakukan dengan menggunakan pendekatan uji Kolmogorof-Simirnov. Hasil penghitungan uji normalitas dapat dilihat pada Tabel 1 .

Tabel 1. Hasil Penghitungan Uji Normalitas Menggunakan Microsoft Excel 2007

\begin{tabular}{llll}
\hline $\begin{array}{l}\text { Aspek } \\
\text { Penilaian }\end{array}$ & $\begin{array}{l}\text { Lo } \\
\text { Hitung }\end{array}$ & $\begin{array}{l}\text { L-Tabel } \\
(0,05: 40)\end{array}$ & Kesimpulan \\
\hline $\begin{array}{l}\text { Kecerdasan } \\
\text { Emosinal }\end{array}$ & & & \\
$\begin{array}{l}\text { Prestasi } \\
\text { Belajar }\end{array}$ & 0,363 & 0,140 & Normal \\
\hline
\end{tabular}

Berdasarkan hasil penghitungan uji normalitas menggunakan Kolmogorof-Simirnov didapatkan kecerdasan emosional dan dari prestasi belajar (0,363). Selanjutnya dibandingkan dengan $L$ tabel $(0,05: 40)$ sebesar $(0,140)$. Dari penyataan tersebut dapat disimpulkan bahwa Lo hitung lebih besar dari pada L-Tabel, dengan demikian dapat dikemukakan bahwa data yang didapatkan hari hasil perhitungan berdistribusi Normal.

Hasil Uji Homogenitas Menggunakan Microsoft Excel 2007

Setelah dilakukan pengujian normalitas, selanjutnya dilakukan pengujian homogenitas dari kedua variansi. Pengujian homogenitas ini menggunakan uji kesamaan dua variansi. Adapun hasil pengujian dua variansi dapat dilihat pada Tabel 2.

Tabel 2. Hasil Uji Homogenitas menggunakan Microsoft Excel 2007

\begin{tabular}{lccc}
\hline \multicolumn{1}{c}{ Aspek } & $\begin{array}{c}\text { F- } \\
\text { Hitung }\end{array}$ & F-Tabel & Hasil \\
\hline $\begin{array}{l}\text { Kecerdasan } \\
\text { Emosional } \\
\text { Prestasi }\end{array}$ & 0,251 & 1,65 & Homogen \\
Belajar & & & \\
\hline
\end{tabular}

Berdasarkan hasil perhitungan data tersebut, dapat diketahui bahwa dari data nilai $\mathrm{F}$ hitung $(0,251)<\mathrm{F}$ tabel $(1,65)$ dengan besarnya $\alpha$ $=0,05$ dan $\mathrm{dk}(40: 40)$, berdasarkan penjelasan tersebut dapat ditarik kesimpulan bahwa pengujian data dari kedua variansi tersebut adalah data yang bersifat HOMOGEN. 
Jurnal Keolahragaan 7 (2), 2019 - 129

Andy Ardian, Sugeng Purwanto, Deden Saepul Alfarisi

Uji Kesamaan dua Rata-rata (Satu Pihak) Menggunakan Microsoft Excel dan Manual

Setelah dilakukan pengujian normalitas dan homogenitas, selanjutnya dilakukan perhitungan kesamaan dua rata-rata untuk mengetahui apakah kecerdasan emosional berpengaruh terhadap prestasi belajar siswa di SMA Negeri 1 Ciparay. Hasil penghitungan dapat dilihat pada Tabel 3.

Tabel 3. Hasil Uji Kesamaan dua Rata-Rata Menggunakan Microsoft Excel 2007

\begin{tabular}{llll}
\hline Aspek Penilaian & $\begin{array}{l}\mathrm{t}- \\
\text { hitung }\end{array}$ & $\begin{array}{l}\mathrm{t} \text { table } \\
(39: \alpha \\
0,05)\end{array}$ & Hasil \\
\hline $\begin{array}{l}\text { Kecerdasan } \\
\begin{array}{l}\text { Emosional } \\
\text { Prestasi Belajar }\end{array}\end{array}$ & 88,974 & 1,684 & Signifikan \\
\hline
\end{tabular}

Dari hasil penghitungan dan analisis data diperoleh $t_{\text {hitung }}$ sebesar $(88,974)$ Selanjutnya dibandingkan dengan $t_{\text {tabel }} 0,05(39)=1,684$ Harga $\mathrm{t}_{\text {hitung }}$ lebih besar dari pada $\mathrm{t}_{\text {tabel }}$, dan $\mathrm{t}_{\text {hitung }}$ berada di dalam daerah penerimaan hipotesis, jadi Kecerdasan Emosional berpengaruh terhadap hasil belajar siswa kelas khusus olahraga di SMA Negeri 1 Ciparay.

Uji Kebermaknan (Signifikansi) Koefisien Korelasi (r)

Kemudian setelah diketahui adanya pengaruh antara kecerdasaran emosional dengan prestasi belajar, selanjutnya dilakukan perhitungan kebermaknaan atau uji signifikansi hubungan antara kedua variabel, perhitungan tersebut dapat dilihat pada penjelasan Persamaan Rumus 1.

Cari $t_{\text {hitung }}$ dengan rumus

$\left.\mathrm{T}_{\text {hitung }}=\sqrt[r]{\frac{n-2}{1-r^{2}}}=(0,369) 1\right)$

Menetapkan taraf signifikansi, yaitu $\alpha=$ 0,05 Tentukan kriteria pengujian signifikansi korelasi, yaitu: Jika $-\mathrm{t}_{\text {tabel }} \leq \mathrm{t}_{\text {hitung }} \leq \mathrm{t}_{\text {tabel }}$, maka $\mathrm{H}_{0}$ diterima atau korelasinya tidak signifikan. Tentukan derajat kebebasan ( $\mathrm{dk}$ ) dengan rumus $\mathrm{dk}=\mathrm{n}-2(40-2=38)$ Dengan taraf signifikansi $\alpha=0,05$ dan dengan menggunakan $t_{\text {tabel }}(2,024)$. Bandingkan $\mathrm{t}_{\text {hitung }}$ dengan $\mathrm{t}_{\text {tabel }}\left(-\mathrm{t}_{(2,042)} \leq \mathrm{t}(0,369) \leq\right.$ $\mathrm{t}_{(2,042)}$. Jadi kesimpulannya terdapat hubungan yang signifikan antara kecerdasan emosional dengan prestasi belajar.

\section{Pembahasan}

Berdasarkan hasil penelitian yang telah dilaksanakan diketahui bahwa kecerdasan emo- sional memiliki pengaruh dan hubungan yang signifikan terhadap prestasi hasil belajar siswa kelas khusus olahraga di SMA Negeri 1 Ciparay. Lebih lanjut, hasil penelitian mengungkapkan jika kecerdasan emosional yang dimiliki siswa merupakan salah satu faktor penting menunjang keberhasilan belajar siswa kelas khusus olahraga. Kajian literatur penelitian-penelitian mengenai kecerdasan emosional yang berhubungan dengan prestasi telah banyak dilakukan, tetapi memiliki keterbatasan untuk kelas khusus olaharga. Meskipun memiliki beberapa keterbatasan mengenai sample pada kelas khusus olaharga kajian literature penelitian-penelitian terdahulu mengungkapkan hasil yang sama dan mendukung hasil penelitian yang telah dilakukan mengenai adanya pengaruh serta hubungan kecerdasan emosional yang dimiliki siswa terhadap prestasi belajar yang diraih.

Sejalan dengan pernyataan tersebut, Daud (2012) mengungkapkan bahwa kecerdasan emosional pengaruh yang positif dan signifikan terhadap hasil belajar Biologi. Lebih lanjut, dalam penelitian ini Daud (2012) menjelaskan bahwa dalam keberhasilan pembelajaran kecerdasan emosional bukanlah satu-satunya faktor pendukung yang harus dimiliki oleh individu, hasil penelitian mengungkapkan bahwa terdapat faktor lain sebagi pendukung keberhasilan belajar siswa yaitu motivasi. Hubungan keduanya juga sangat berpengrauh besar dan positif terhadap hasil pembelajaran biologi. Yuliantini (2013) mengungkapkan bahwa kecerdasan emosional seorang individu memiliki signifikansi positif terhadap prestasi belajar. Semakin tinggi tingkat kecerdasan emosional individu maka semakin besar kemungkinan keberhasilan belajar dan prestasi belajar yang diraih. Lebih lanjut ia menjelaskan bahwa selain kecerdasan emosional yang dimiliki oleh individu, motivasi juga merupakan salah satu faktor pendukung dari keberhasilan dalam meraih prestasi belajar. Hasil penelitian menunjukkan bahwa kecerdasan emosional dan motivasi berprestasi yang dimiliki secara bersamaan merupakan hal penting dalam keberhasilan prestasi belajar. Yuliantini, kembali menjelaskan bahwa faktor yang paling dominan dalam keberhasilan seorang individu adalah kecerdasan emosional yang tinggi serta motivasi belajar yang tinggi, keduanya jika dimiliki seseorang dan masuk dalam kategori tinggi sangat besar mempengaruhi prestasi belajar, dibandingkan dengan hanya satu faktor dalam kategori tinggi.

Purnama (2016) mengatakan bahwa terdapat pengaruh tidak langsung yang signifikan 
Jurnal Keolahragaan 7 (2), 2019 - 130

Andy Ardian, Sugeng Purwanto, Deden Saepul Alfarisi

kecerdasan emosional terhadap prestasi belajar matematika melalui minat belajar matematika. Upaya meningkatkan prestasi belajar matematika siswa dapat dilakukan dengan meningkatkan kecerdasan emosional siswa dan minat belajar matematika siswa. Kecerdasan emosional siswa dapat ditingkatkan melalui kesadaran diri terhadap lingkungan sosialnya sehingga kecerdasan emosional siswa meningkat dan minat belajar matematika siswa ikut meningkat. Selain kecerdasan emosional yang tinggi yang dapat meningkatkan minat belajar matematika siswa metode yang guru gunakan dalam mengajar juga dapat meningkatkan minat belajar matematika. Agustina et al. (2017) mengungkapkan bahwa kecerdasan emosional memiliki pengaruh yang positif terhadap keberhasilan belajar biologi pada siswa/siswi SMA. Hasil penelitian juga mengungkapkan bahwa selain kecerdasan emosional terdapat faktor lain juga yang mempengaruhi keberhasilan belajar yaitu kecerdasan intelektual, hal ini dibuktikan dengan hasil niali ujian akhir yang baik pada mata pelajaran biologi. Lebih lanjut, Agustina et al. (2017) mengungkapkan bahwa prestasi belajar pada mata pelajaran biologi yang paling cemerlang didapat dari siswa yang memiliki keseimbangan antara kecerdasan emosional dan kecerdasan intelektual yang dimiliki, hal ini dimaksudkan adalah siswa yang masuk dalam kategori tinggi dalam kecerdasan emosional dan intelektual lebih memiliki prestasi cemerlang dibandingkan dengan siswa yang hanya memiliki satu kategori tinggi antara kecerdasan emosional dan kecerdasan intelektual.

Almubarak (2016) mengungkapkan bahwa prestasi belajar mahasiswa dipengaruhi oleh beberapa faktor. Faktor dominan yang berhubungan signifikan mempengaruhi keberhasilan mahasiswa dalam kuliah adalah kecerdasan emosional yang dimilikinya. Semakin besar kecerdasan emosional yang dimiliki maka akan semakin besar kemungkinan keberhasilan dalam prestasi belajar mahasiswa dibandingkan dengan mahasiswa yang memiliki tingkat kecerdasan emisonal yang rendah. Lebih lanjut, (Almubarak, 2016), mengungkapkan bahwa selain kecerdasan emosional terdapat faktor lainya yang mempengaruhi tetapi itu di luar kontes penelitian ini. Putro (2017) menjelaskan bahwa terdapat pengaruh yang positif dan signifikan antara fasilitas pembelajaran terhadap prestasi akademik mahasiswa Pendidikan Ekonomi UNS; (4) koefisien determinasi ( $\mathrm{R}$ Square) sebesar 0,424. Hal tersebut berarti bahwa $42,4 \%$ prestasi akademik mahasiswa dipengaruhi oleh kecerdasan emosional dan fasilitas pembelajaran, sedangkan sisanya sebesar 57,6\% dipengaruhi oleh faktor lain di luar penelitian ini. Hadiwijaya (2017) mengungkapkan bahwa ada pengaruh yang signifikan antara prestasi belajar biola siswa dan kecerdasan emosi siswa sekitar $76,1 \%$, sedangkan sisanya $23,9 \%$ dipengaruhi oleh faktor lain yang tidak diteliti dalam penelitian ini. Saya membuktikan bahwa belajar biola sangat memengaruhi kecerdasan emosional dan kecerdasan emosional siswa berpengaruh dalam meningkatkan prestasi siswa. Dari data, itu menunjukkan bahwa sebagian besar para siswa yang berpartisipasi dalam ekstrakurikuler biola dapat meningkatkan prestasi belajar mereka. Shuib et al. (2018) mengungkapkan bahwa kecerdasan emosional dalam penelitian ini yang mencakup, motivasi diri, self-regulasi, spiritualitas, kesadaran diri, empati dan kepercayaan diri memiliki pengaruh yang signifikan terhadap pencapaian keberhasilan belajar pada siswa di Malaysia.

Setyawan and Simbolon (2018) menjelaskan bahwa kecerdasan emosional yang dimiliki seseorang akan mempengaruhi prestasi belajar pada mata pelajaran matematika, terdapat pengaruh kecerdasan emosional terhadap hasil belajar matematika. Sehingga perlu diupayakan pengembangan kecerdasan emosional yang dimiliki oleh siswa. Dalam hal ini guru harus bisa melatih dan mengasah kemampuan kecerdasan emosional dengan baik. Dalam mengelola konsentrasi, kesabaran, dan ketelitian dibutuhkan motivasi dan pengelolaan kecerdasan emosional yang kuat, sehingga siswa tidak mudah putus asa dan menyerah ketika siswa belum dapat menemukan jawaban penyelesaian yang tepat pada pembelajaran matematika. (Kusnaedi, 2018) mengungkapkan bahwa tingkat aktiviatas dalam pembelajaran jasmani pada SMA Muhamadiyah 1 Semarang dipengaruhi oleh kecerdasan emosional individu masing-masing. Hasil penelitian mengungkapkan bahwa seseorang yang baik dalam melakukan aktivitas pada pembelajaran jasmani memiliki tingkat kecerdasam emosional yang tinggi dan juga sebaliknya seseorang yang malas dan tidak terlalu tertarik dalam melakukan aktivitas pada pembelajaran jasmani memiliki kecerdasan emosional yang lebih rendah. Penelitian ini juga mengungkapkan bahwa bukan hanya kecerdasan emosional yang mempengaruhi aktivitas pada pembelajaran jasmani, terdapat faktor lain yang tidak diteliti dalam penelitian ini.

Laumara et al. (2018) mengungkapkan bahwa kecerdasan emosional memiliki pengaruh terhadap prestasi belajar, selain kecerdasan emo- 
Jurnal Keolahragaan 7 (2), 2019 - 131

Andy Ardian, Sugeng Purwanto, Deden Saepul Alfarisi

sional faktor yang mempengaruhi prestasi belajar siswa adalah motivasi. Berbicara mengenai kecerdasan emosional, hal ini berdasarkan hasil penelitianya yang mengungkapkan jika terdapat beberapa kategori kecerdasan emosional yang dimiliki siswa yaitu, sejumlah 9 siswa $(15,25 \%)$, kemudian pada kategori Sedang sejumlah 34 siswa $(57,63 \%)$ dan pada kategori Rendah sejumlah 16 siswa $(27,12 \%)$, prestasi yang dimiliki siswa yang memiliki kecerdasan emosional tinggi berbeda dengan siswa yang memiliki kecerdasan emosional rendah, sehingga dapat dikatakan bahwa kecerdasan emosional merupakan salah satu faktor pendukung dalam keberhasilan prestasi yang didapatkan siswa.

Hartini and Yasin (2019) mengungkapkan bahwa terdapat beberpa faktor yang mempengaruhi keberhasilan belajar pada mata pelajaran sejarah siswa XI SMA, faktor-faktor itu antara lain yaitu, hubungan positif dan signifikan antara layanan bimbingan konseling dengan prestasi belajar sejarah, terdapat hubungan positif antara kecerdasan emosional dengan prestasi belajar sejarah siswa kelas XI SMA, terdapat hubungan positif antara layanan bimbingan konseling dan kecerdasan emosional bersama-sama dengan prestasi belajar sejarah siswa kelas XI SMA. Lebih lanjut penelitian ini mengungkapkan, selain faktor yang disebutkan diatas terdapat faktor lain yang mempengaruhi keberhasilan belajar yaitu motivasi, konsentrasi dan dorongan dari orang tua

Meskipun beberapa penelitian terdahulu mengungkapkan hal yang sama dengan hasil penelitian yaitu adanya hubungan dan pengaruh kecerdasan emosional terhadap keberhasilan belajar siswa, terdapat perbedaan pandangan hasil penelitian yang mengungkapkan jika kecerdasan emisonal tidak memiliki pengaruh dan hubungan yang signifikan terhadap hasil belajar. Sejalan dengan pernyataan tersebut, penelitian Prasetiyo et al. (2018) menjelaskan bahwa tidak ada perbedaan kecerdasan emosional antara mahasiswa yang aktif dalam kegiatan UKM Olahraga dengan mahasiswa yang tidak mengikuti UKM Olahraga Prodi Pendidikan Jasmani dan Kesehatan STKIP PGRI Jombang. Lebih lanjut, ia menjelaksn bahwa prestasi yang dimiliki mahasiswa dipengaruhi oleh faktor lain seperti fisik dan taktik.

Nurkholis (2009) menjelaskan bahwa peningkatan kualiatas pembelajaran tidak dipengaruhi oleh kecerdasan emosional dan kecerdasan intelektual. Namun kecerdasan emosional bisa ditingkakan melalui metode pembelajaran meng- gunakan metode bermain. Namun secara keseluruhan penelitian ini menunjukan bahwa kualitas pembelajaran tidak ada hubungan signifikan dengan kecerdasan emosional yang dimiliki seseorang. Ranjbar et al. (2017) menyebutkan bahwa kecerdasan emosional tidak memiliki hubungan yang signifikan terhadap hasil prestasi pendidikan pada mahasiswa Iran. Hasil penelitian mengungkapkan bahwa tampaknya hubungan konsepkonsep ini dapat dipengaruhi oleh faktor lain dalam pengaturan ini, jadi ini membutuhkan studi lebih lanjut di bidang ini. Kecerdasan emosional yang dimiliki seseorang dapat ditingkatkan dengan memberikan pelatihan mental. Namun, kecerdasan emosional yang dimiliki oleh seseorang bukan merupakan faktor penentu keberhasilan dalam meraih keberhasilan prestasi belajar. Terdapat faktor lain yang lebih dominan dalam menjadi faktor pendorong keberhasilan dalam prestasi belajar seorang individu (Kaviani $\&$ Saadatmand, 2018).

Irmawati et al. (2016) mengungkapkan bahwa tidak ada hubungan kecerdasan emosional terhadap prestasi belajar mahasiswa ditinjau dari jenis kelamin pada jurusan pendidikan matematika angkatan 2012, 2013, dan 2014 UIN Alauddin Makassar dengan taraf signifikan 5\% atau ( $\alpha$ $=0,05)$. Lebih lanjut, Irmawati et al. (2016) menjelaskan bahwa prestasi belajar mahasiswa disebebkan oleh faktor lainya seperti motivasi, dorongan orang tua dan belajar mandiri. Hartika dan Mariana (2019) menjelaskan bahwa dari hasil analisis data yang telah dilakukan dapat diketahui bahwa hasil penelitian ini menunjukan tidak ada pengaruh yang signifikan antara variabel keaktifan belajar dan kecerdasan emosional terhadap prestasi belajar mahasiswa Universitas Banten Jaya. Hal ini dibuktikan dari hasil perhitungan analisis statistik yang telah dilakukan dan diperoleh hasil demikian. Keaktifan belajar terhadap prestasi belajar dipengaruhi oleh faktor lainnya. Meskipun kecerdasan emosional bukan faktor dominan yang mempengaruhi prestasi belajar Mahasiswa, akan tetapi kecerdasan emosional tetap tidak boleh diabaikan begitu saja sebab kecerdasan emosional dapat mendukung faktorfaktor lain yang lebih dominan dan dapat menjadikan mahasiswa meningkatkan prestasi belajarnya. Koc (2019) mengungkapkan bahwa keberhasilan seseorang tidak dipengaruhi oleh kecerdasan emosional yang dimiliki, keberhasilan yang diperoleh dipengaruhi oleh faktor lain yang berasal dari dalam maupun dirinya. Lebih lanjut, Koc, menjelaskan bahwa dorongan belajar dari dalam diri seperti motivasi yang dimiliki 
Jurnal Keolahragaan 7 (2), 2019 - 132

Andy Ardian, Sugeng Purwanto, Deden Saepul Alfarisi

merupakan faktor yang sangat penting dan mendorong keberhasilan seseorang.

Nazidizaji et al. (2014) mengungkapkan bahwa tidak adanya hubungan yang signifikan antara kecerdasan emosional yang dimiliki oleh siswa terhadap perkembangan pembelajaran serta prestasi pada siswa arsitektur. Selain kecerdasan emosional, kecakapan komunikasi personal juga bukan merupakan faktor yang penting untuk diperhatikan dalam perkembangan dan prestasi belajar dalam bidang arsitektur. Farhan dan Alfin (2019) Kecerdasan emosional yang dimiliki oleh siswa tidak memiliki hubungan dan pengaruh yang signifikan terhadap hasil pembelajaran, selain kecerdasan emosional keyakinan diri juga bukan merupakan salah satu pendorong dalam keberhasilan prestasi belajar. Lebih lanjut, Farhan dan Alfin (2019) menjelaskan kedua variabel tersebut antara kecerdasan emosional dan keyakinan diri secara bersamaan juga tidak memiliki pengaruh dan hubungan yang signifikan terhdap hasil prestasi belajar siswa. Faktor-faktor yang berpengaruh besar dalam keberhasilan belajar siswa yaitu interaksi lebih banyak dengan lingkungan luar dibandingkan untuk interaksi yang terjadi dalam lingkungan keluarga, karena kebiasaan siswa ketika kembali dari sekolah jangan langsung pergi rumah tetapi melakukan kegiatan lain di luar dan hal itu menyebabkan kurangnya perhatian siswa pada aturan yang berlaku di sekolah. Sehingga peraturan tersebut menjadi tidak optimal kemudian berdampak kepada norma yang berlaku disy sekolah sering diabaikan oleh siswa. Nanda dan Dimyati (2019) mengungkapkan jika kecerdasan emosional merupakan bagian dari keterampilan psikologis yang merupakan faktor penting dalam menunjang keberhasilan prestasi yang diraih oleh individu.

Berdasarkan hasil penelitian dan pembahasan terdapat persamaan dan perbedaan antara hasil penelitan dengan teori dan hasil penelitian pendahuluan. Persamaan ataupun perbedaan ini diharapkan mampu menjadikan landasan atau rujukan untuk melakukan penelitian selanjutnya. Secara garis besar diungkapkan bahwa kecerdasan emosional yang dimiliki setiap manusia dapat mempengaruhi dan tidak keberhasilan prestasi belajar dalam berbagai bidang mata pelajaran. Meskipun kecerdasan emosional mempengaruhi terdapat bebebrapa faktor lain yang tidak diteliti di penelitian ini yang diharapkan mampu diungkapkan pada penelitian lainya.

\section{SIMPULAN}

Kesimpulan yang dapat ditarik berdasarkan hasil penelitian adalah adanya hubungan prestasi yang didapatkan siswa dengan kecerdasan emosional yang dimilikinya. Makin tinggi kecerdasan emosional yang dimiliki maka semakin besar prestasi dalam pembelajaran yang didapatkan oleh siswa kelas khusus olaharga. Hasil penelitian ini diharapkan dapat menjadi rujukan bagi guru untuk meningkatkan kecerdasan emosional siswa yang masih rendah agar dapat ditingkatkan demi prestasi belajar yang cemerlang. Hasil penelitian ini juga diharapkan dapat menjadi rujukan untuk penelitian selanjutnya tetapi bisa ditambahkan variabel lain yang menunjang keberhasilan prestasi belajar siswa khusunya untuk kelas olahraga.

\section{DAFTAR PUSTAKA}

Agustina, T., Restuati, M., \& Asphani, F. (2017). Hubungan kecerdasan emosional dan kecerdasan intelektual terhadap hasil belajar biologi siswa pada materi sistem saraf di SMA Asy-Syafi'iyah Medan. Jurnal Pendidikan Matematika Dan Sains, 12(1).

https://jurnal.unimed.ac.id/2012/index.ph p/jpms/article/view/9002

Almubarak, A. (2016). Analisis hubungan kecerdasan emosional terhadap prestasi belajar kimia prodi pendidikan kimia FKIP ULM. Seminar Nasional Pendidikan Kimia Peran STeM (Science, Technology, and Mathematics), 233-246. http://eprints.ulm.ac.id/2580/

Andiri, L., Jajat, \& Sultoni, K. (2017). Hubungan kecerdasan emosi dengan prestasi akademik mahasiswa olahraga. Jurnal Terapan Ilmu Keolahragaan, 2(2), 137. https://doi.org/10.17509/jtikor.v2i2.8063

Chubba, D. (2007). Hubungan antara kecerdasan emosional dengan prestasi belajar siswa kelas XI SMA Wachid Hasyim Surabaya [Universitas Islam Negeri Maulana Malik Ibrahim]. http://etheses.uin-malang.ac.id/8596/

Dartija, D. (2014). Hubungan antara kecerdasan emosional dengan prestasi belajar pendidikan jasmani siswa SMP Negeri 1 Sawang Kabupaten Aceh Selatan. Penjaskesrek Journal, 1(1). https://penjaskesrek.stkipgetsempena.ac.i $\mathrm{d} /$ ?journal=home \&page $=$ article $\&$ op $=$ view 
Jurnal Keolahragaan 7 (2), 2019 - 133

Andy Ardian, Sugeng Purwanto, Deden Saepul Alfarisi

\&path $\% 5 \mathrm{~B} \% 5 \mathrm{D}=3$

Daud, F. (2012). Pengaruh kecerdasan emosional (EQ) dan motivasi belajar terhadap hasil belajar biologi siswa SMA 3 Negeri Kota Palopo. Jurnal Pendidikan Dan Pembelajaran (JPP), 19(2), 243-255. http://journal.um.ac.id/index.php/pendidik an-dan-pembelajaran/article/view/3475

Farhan, M., \& Alfin, E. (2019). The effect of emotional intelligence and self effycacy towards students achievement. JIPM (Jurnal Ilmiah Pendidikan Matematika), 8(1), 37-46. https://doi.org/10.25273/jipm.v8i1.4669

Fitriyah, H. (2011). Pelaksanaan program kelas akselerasi di SMP Negeri 1 Sragen tahun 2009-2010. Universitas Sebelas Maret.

Goffreda, C. T., Diperna, J. C., \& Pedersen, J. A. (2009). Preventive screening for early readers: Predictive validity of the Dynamic Indicators of Basic Early Literacy Skills (DIBELS). Revista de Educacion, 46(6), 539-552.

https://doi.org/10.1002/pits.20396

Hadiwijaya, H. (2017). Effect of emotional intelligence on student learning achievement. GUIDENA: Jurnal Ilmu Pendidikan, Psikologi, Bimbingan Dan Konseling, 7(1). https://doi.org/10.24127/gdn.v7i1.663

Hartika, N., \& Mariana, F. (2019). Pengaruh keaktifan belajar \& kecerdasan emosional terhadap prestasi belajar mahasiswa (Studi pada Program Studi Pendidikan Akuntansi Fakultas Keguruan \& Ilmu Pendidikan Universitas Banten Jaya). PROGRESS Jurnal Pendidikan, Akuntansi Dan Keuangan, 2(1), 57-71. http://ejournal.lppm-

unbaja.ac.id/index.php/progress/article/vi ew/490

Hartini, T., \& Yasin, M. F. (2019). Hubungan antara program layanan bimbingan konseling dan kecerdasan emosional dengan prestasi hasil belajar sejarah kelas XI SMA Bekasi. Akademika Jurnal Teknologi Pendidikan, 8(1), 71-83. https://doi.org/10.34005/akademika.v8i01 .334

Irmawati, I., Tayeb, T., \& Idris, R. (2016). Hubungan kecerdasan emosional terhadap prestasi belajar mahasiswa ditinjau dari jenis kelamin pada jurusan pendidikan matematika UIN Alauddin Makassar. MaPan: Jurnal Matematika Dan Pembelajaran, 4(2), 156-170. https://doi.org/10.24252/mapan.2016v4n2 a1

Kaviani, S., \& Saadatmand, Z. (2018). The effectiveness of cooperative teaching method in mental health subject on the dimensions of emotional intelligence and academic achievement. International Journal of Educational and Psychological Researches, 4(1), 6-11. https://doi.org/10.4103/jepr.jepr_77_16

Koc, S. E. (2019). The relationship between emotional intelligence, self-directed learning readiness and achievement. International Online Journal of Education and Teaching, 6(3), 672-688.

Kusnaedi, R. (2018). Tingkat aktivitas jasmani terhadap kecerdasan emosional pada remaja di SMA Muhammadiyah 1 Semarang [Universitas Muhammadiyah Semarang]. http://repository.unimus.ac.id/2057/

Laumara, I., Humaedi, H., \& Abduh, I. (2018). Pengaruh kecerdasan emosional dan motivasi belajar terhadap hasil belajar pendidikan jasmani siswa di MTsN AlIkhlas Kilo. Tadulako Journal Sport Sciences And Physical Education, 6(1), $15-21$.

http://jurnal.untad.ac.id/jurnal/index.php/ PJKR/article/view/11083

Luan, J. J. S. A., \& Blegur, J. (2018). Potret kecerdasan emosional mahasiswa pada perkuliahan seminar pendidikan jasmani. Sebatik, 23(1), 195-202. https://www.jurnal.wicida.ac.id/index.php /sebatik/article/view/469

Mahendra, A. (2010). Artikel pokok-pokok pikiran manajemen kelas olahraga. Kementerian Pemuda dan Olahraga Republik Indonesia.

Nanda, F. A., \& Dimyati, D. (2019). Psychological skills of Indonesian basketball athletes in Asian Games 18. ACTIVE: Journal of Physical Education, Sport, Health and Recreation, 8(1), 37-43. https://doi.org/10.15294/active.v8i1.2882 3

Narwoto, N., \& Soeharto, S. (2013). Faktorfaktor yang berpengaruh terhadap prestasi belajar teori kejuruan siswa SMK. Jurnal 
Jurnal Keolahragaan 7 (2), 2019 - 134

Andy Ardian, Sugeng Purwanto, Deden Saepul Alfarisi

Pendidikan Vokasi, 3(2). https://doi.org/10.21831/jpv.v3i2.1603

Nazidizaji, S., Tomé, A., \& Regateiro, F. (2014). Search for design intelligence: A field study on the role of emotional intelligence in architectural design studios. Frontiers of Architectural Research, 3(4), 413-423. https://doi.org/10.1016/j.foar.2014.08.005

Nurkholis, N. (2009). Meningkatkan kecerdasan emosi dan inteligensi siswa melalui peningkatan kualitas pembelajaran pendidikan jasmani. Jurnal Ilmu Pendidikan, 16(2), 112-118. https://doi.org/10.17977/jip.v16i2.2563

Prasetiyo, R., Puspitaningsari, M., \& Sinthyawati, N. N. (2018). Perbedaan kecerdasan emosional antara mahasiswa aktif dalam ukm olahraga dengan mahasiswa yang tidak mengikuti UKM olahraga (Studi pada Program Studi Pendidikan Jasmani dan Kesehatan STKIP PGRI Jombang). Bravo's: Jurnal Program Studi Pendidikan Jasmani Dan Kesehatan, 6(2), 49-58. https://doi.org/10.32682/bravos.v3i1.257

Pujiatmojo, S. (2012). Bagaimana konsep kelas akselerasi berjalan. Rajutan Inspirasi. http://sigitpujiatmojo.blogspot.com/2012/ 02/bagaimana-konsep-kelasakselerasi.html

Purnama, I. M. (2016). Pengaruh kecerdasan emosional dan minat belajar terhadap prestasi belajar matematika di SMAN Jakarta Selatan. Formatif: Jurnal Ilmiah Pendidikan MIPA, 6(3), 233-245. https://doi.org/10.30998/formatif.v6i3.995

Purnamasari, A. D., Nurseto, F., \& Tarigan, H. (2013). Hubungan antara kecerdasan emosional dengan hasil belajar keterampilan dasar sepakbola siswa. JUPE (Jurnal Penjaskesrek), 1(3). http://jurnal.fkip.unila.ac.id/index.php/JU PE/article/view/1255

Putro, S. A. (2017). Pengaruh kecerdasan emosional dan fasilitas pembelajaran terhadap prestasi akademik mahasiswa pendidikan ekonomi UNS. Universitas Sebelas Maret.

Ranjbar, H., Khademi, S. H., \& Areshtanab, H. N. (2017). The relation between academic achievement \& emotional intelligence in Iranian students: A meta-Analysis. Acta Facultatis Medicae Naissensis, 34(1), 6576. https://doi.org/10.1515/afmnai-20170008

Retnowati, D. R., Fatchan, A., \& Astina, I. K. (2016). Prestasi akademik dan motivasi berprestasi mahasiswa S1 pendidikan geografi Universitas Negeri Malang. Jurnal Pendidikan: Teori, Penelitian, Dan Pengembangan, 1(3), 521-525. https://doi.org/10.17977/jp.v1i3.6181

Rohmah, N. (2018). Integrasi kecerdasan intelektual (IQ), kecerdasan emosi (EQ) dan kecerdasan spiritual (SQ) dalam meningkatkan etos kerja. Tarbiyatuna: Jurnal Pendidikan Ilmiah, 3(2), 77-102. http://ejournal.kopertais4.or.id/mataraman /index.php/tarbiyatuna/article/view/3525

Setyawan, A. A., \& Simbolon, D. (2018). Pengaruh kecerdasan emosional terhadap hasil belajar matematika siswa SMK Kansai Pekanbaru. JPPM (Jurnal Penelitian Dan Pembelajaran Matematika), 11(1). https://doi.org/10.30870/jppm.v11i1.2980

Shuib, N. H., Ishak, N. M., Amat, S., \& Ahmad, I. (2018). Emotional intelligence and academic achievement of primary school students in Malaysia. Social Science and Humanities Journal, 2(9), 594-601. http://sshj.in/index.php/sshj/article/view/2 28

Tridhonanto, A. (2010). Meraih sukses dengan kecerdasan emosional. Elex Media Komputindo.

Yuliantini, T. (2013). Pengaruh kecerdasan emosi (EQ) dan motivasi berprestasi terhadap prestasi belajar mahasiswa Akparnas-UNAS Jakarta. Jurnal MIX, III(1), 58-71. 